Lesbian women's experience of coming out in an Irish hospital setting

\begin{abstract}
There is a dearth of knowledge about lesbian women's lives and social experiences in Irish society. In their day to day living lesbian women know how to act, react and behave to exist within society, having developed what Draucker (1999 p. 361) calls 'everyday skilful coping'. However these taken-for-granted ways of understanding of being in the world are thrown or brought to the forefront when lesbian women seek health care. The overall aim of the research is to investigate lesbian women's experiences of Irish health care as service users. Within this article I will explore how four lesbian women understand and give meaning to 'coming out' to a health care provider. Coming out is a precarious affair whereby lesbian women choose when, where and to whom to relate their sexuality. The experiences of these women are explored by utilising Sartre's (1969) concepts of being objectified by the Other, shame, freedom, illustrating how the self can be disrupted.
\end{abstract}

Keywords: Lesbian, Health Care, Hermeneutic Phenomenology, Sartre, Heidegger

\title{
Introduction
}

The process of 'coming out' for lesbian women is the point of knowing who they are (Rust 1993), with no such comparable practice for heterosexuals in society (Bradford, Ryan \& Rothblum 1997). 'Knowing who one is' is to know where one belongs, a sense of rootness, a sense of community which encapsulates a sense of self. For most lesbian women, 'coming out' is a life-long process, facilitating the need for self-affirmation, validation and acceptance by others (Chirrey 2003). It involves making decisions on whether to disclose or not to disclose, based upon the lesbian woman's comfortableness with the self, situations and in some cases upon the past experience(s) of disclosure(s). Research has shown that coming out in health care is important, resulting in the visibility of lesbian women (Enszer 1996), provision of adequate health care (Marrazzo \& Stine 2004) and building trust relationships with health care providers (White \& Dull 1997). This article presents four lesbian women's experiences of 'coming out' in Irish health 
care from a hermeneutic phenomenological perspective. A description of the theoretical and methodological approach adopted for this research is provided and implications for Irish health care health care policy are also discussed.

\section{Lesbianism in Ireland}

Lesbian women confront the reality of being lesbian every day in Irish society. They exist within a predominately heterosexual society, in which institutions such as: family (Hug 1999), education (Norman, Galvin \& McNamara 2006) and religion (Kenny 1997), reflect heterosexual norms, placing lesbian women on the margins of that society. This in turn reflects the limited knowledge of many in that society about lesbian women's lives and social experiences thus rendering them invisible (Lemon \& Patton 1997).

O'Connor (1998) began her work on women in Ireland with the words: '[A]ny discussion of changes in the position of women in Irish society over the past thirty years tends to elicit two views: that it has changed completely, and that is has not changed at all' (p. 1). This could easily apply to lesbian women. Although there have been enormous changes in Irish society, such as the decriminilisation of homosexuality in 1993, the Employment Equality Act, 1997, the Equal Status Act, 2000, and the Civil Partnership Act, 2010, lesbian women remain invisible.

The first Irish research on sexual health and relationships was published in 2006 (Layte et al. 2006). From the findings it is clear that there has been changes in public attitude towards lesbian women and gay men, with $53 \%$ indicating that sex between same-sex 
couples was 'never wrong' (Layte et al. 2006). They indicate that even though the stigma attached to being lesbian or gay 'has decreased in recent decades, it is still pronounced in Irish society' concluding that 'all estimates of same-sex attraction, experience and identity based upon self-report should be seen as under-estimate' (Layte et al. 2006, p. 127). The results of this research may indicate that lesbian, gay or bisexual individuals experience stigmatisation if they do not feel secure enough to identify themselves in a confidential questionnaire.

\section{'Coming out'}

For lesbian women to get to the point of knowing who they are, they go through a process known as 'coming out', which has no comparable process for heterosexual women (Bradford, Ryan \& Rothblum, 1997). Rust (1993) indicates it is 'a process of describing one's social location within a changing social context' (p. 25). Chirrey (2003) suggests that 'coming out' is that 'moment of recognizing and asserting their gayness' (p. 24). A lesbian woman has not only to 'come out' to herself but also to her family, friends or coworkers. For most lesbian women 'coming out' is a life-long process, facilitating the need for self-affirmation, validation, the acceptance of others and the need to meet potential partners. 'Coming out' is not a process that has a neat beginning and end, but one that continues throughout the life cycle. It may begin as early as thirteen years (Clunis et al 2005) of age, or as late as the thirties or forties depending on the availability of knowledge, that is, if lesbianism is spoken about, or literature available within a community and society (Claassen 2005). There are other personal and social factors that 
influence the coming out process such as the internalisation of homophobia (Brogan 1997) and coming to terms with the social stigma of being lesbian (Layte 2006)

However, this process maybe misrepresented in society: heterosexuals may hold negative attitudes and connotations of 'coming out', seeing it as 'flaunting sexual activity, imposing on the sensitivities of others, or revealing personal information inappropriately' (Johnson \& Guenther 1987, p. 234). Heterosexuals do not have to declare their sexuality, as it is the norm. It would appear that in order to 'come out' as lesbian, a woman must undo all her understanding of the structures of society. She must create a new way of being within a dominant heterosexual culture. For instance a lesbian woman must be able to recognise herself as lesbian while simultaneously existing within a heterosexual society. Within this article I will explore how a lesbian woman does this in Irish health care.

\section{Lesbian Women's Experience of Health Care}

Over the last twenty-five years, research has been carried out on lesbian women's experience or perceived experiences of health care provision by health care providers (Marrazzo \& Stine 2004). Lesbian women attend health care services less often than heterosexual women (Fields \& Scout 2001). The reasons for non-access relate to ambivalence as to whether they need health care or not (White \& Dull 1998), and/or lesbian women may not consider themselves to be exposed to the same risk factors for illness and infections as heterosexual women (Enszer 1996). Bonvicini \& Perlin (2003) suggests that the greatest health risk for lesbian women is their avoidance of routine 
health care such as pap smears and breast checks. Regan (1981) suggests the problems facing lesbian women are twofold: 'those that face women in general with dealing with the medical profession and those specific to being lesbian' (p. 21). Lesbian women avoid health care services either from fear of discrimination or experience of judgements made by health care professionals on sexual identity and sexuality [sexual practice] (Marrazzo, Coffey \& Bingham 2005).

The issues uncovered in international health care research were reflected by Irish lesbian women in the first seminar held on lesbian health in 1999 (LEA [Lesbian Education and Awareness] \& Western Health Board 1999). These were:

1. Reluctance to disclose sexual identity due to prejudice, oppression and internal homophobia amongst health professionals.

2. Fear that disclosure may affect quality of care.

3. Consequent withholding of personal details, which may have an impact on medical history and diagnosis.

4. Fear that a lesbian partner will not be recognised as next of kin and not treated accordingly.

5. Fear that disclosure of sexual identity will not be treated confidentially; fear family members and others will have access to medical notes, charts etc.

6. The invisibility of women's and lesbian issues in health services; lack of appropriate health promotion material targeted at lesbian and bisexual women.

7. The resistance of many health practitioners to developing more inclusive practices for fear of alienating the majority heterosexual population.

8. The gender bias in gay health: an over-emphasis on AIDS and HIV issues (LEA \& Western Health Board 1999 p.3).

These were later reflected in Gibbons et al. (2007) research in the North Western Region of Ireland, which reflects international research namely: disclosure of sexual orientation (Spinks, Andrews \& Boyle 2000); recognition of partnerships/next of kin (Tiemann, Kennedy \& Haga 1998); parenthood (Lehmann et al 1998); mental health and sexual/gynecological health (Gibbons et al. 2007). 


\section{Theoretical Framework}

This article investigates the theme of 'coming out' in a hospital setting using a hermeneutic phenomenological approach. It is underpinned by the philosophy of Heidegger (1963) and Sartre (1969) because they provided me with a way of thinking about being an authentic self in health care. I chose the hermeneutic or interpretative phenomenological perspective, as the framework for this research, as it enabled me to answer the question: What are the lived experiences of lesbian women of Irish health care?

Phenomenology seeks to understand a phenomenon as it presents itself to me or you as conscious human beings. Social experiences, things (inanimate objects) and events have no meaning in and of themselves; they only hold meaning because human beings confer them with meaning (Jones 2003). A phenomenological approach 'describes the meaning of the lived experiences for several individuals about a concept or the phenomenon' (Creswell 1998, p. 51). It is concerned with how individuals experience a phenomenon, how they describe, interpret and understand the phenomenon under investigation. Bergum (1989) indicates that the lived experience goes beyond the taken-for-granted characteristics of life. It is the interpretation and meanings that individuals give to everyday life experiences. I act towards things based on the interpretations and meanings I have given to previous experiences of similar situations. In this way, individuals create their own reality, which may be similar or different, to that of other individuals experiencing the same situation. 
Heidegger (1962) was concerned with being in the world and he offers a theoretical framework whereby lesbian women can be seen as active participants in the world, creating understanding and meaning in their existence. The essence of Heidegger's phenomenology is 'Dasein' which he refers to as the human being in the world: 'The 'essence' of Dasein lies in its existence' (Heidegger 1962, p. 67). Johnson (2000) suggests that Heidegger views the human being as 'always involved in the practical world of experience' (p. 136). As Heidegger (1962) indicates 'Being-in-the-world is a basic state of Dasein' (p. 86). Being-in-the-world of health care for lesbian women as service users is as an outsider, rendering them vulnerable to the knowledgeable professional (Saulnier 2002). Lesbian women's susceptibility in health care has been well documented: with judgments about sexual orientation (Marrazzo, Coffey \& Bingham 2005), and use of heterosexual language (McDonald, McIntyre \& Anderson 2003), being of particular relevance to the study of 'coming out' in hospital settings.

Sartre (1969) offers a lens through which researchers can examine how lesbian women experience the self, as service users. In particular I wanted to know how lesbian women remain lesbian, that is, maintain their sense of identity within health care encounters. Sartre's focus is on the consciousness of being, where meaning comes from human beings' "meaning-giving" (Moran 2000, p. 357). Meaning is not outside the human being, but within. It is this capturing of life as it is lived, that frames the articulation of understanding and meanings that lesbian women derive from the situations they find themselves in, such as health care. 
Sartre was interested in the question of subjectivity, suggesting that it was free, not constrained by religion or any other controlling factors, as an individual is not a means to an end, but an end in her/himself. The individual must create her/himself. This is similar to Heidegger's idea that the human being is not complete, but constantly becoming:

' $\mathrm{S}[\mathrm{H}] \mathrm{e}$ needs the other, not only to live and make the species live, but also to assert her[him]self, to get recognition, as the child by her[his] parents or the artist by her[his] public, and to enter into collaboration, since her[his] freedom is finite and wants to be carried over to the freedom of others' (Dufrenne 1965, p. 55).

Consequently the individual does not create her/his potential as an island; as Sartre indicates; the individual needs the Other and seeks her/him out. The lesbian woman in health care needs the provider to create her health potential, so underlining the dual focus.

\section{Methodology}

Following ethical approval by Dublin City University Ethics Committee, an advertisement seeking lesbian women who experienced health care was placed in the April 2006 issue of Gay Community News (GCN). GCN is a free community newspaper available through large bookstore outlets, or by direct mail to individual homes (for a small fee). Data gathering took place between April and May 2006. Twelve lesbian women were interviewed about their experiences of Irish health care. Four participants' voices are presented here as they told their stories of 'coming out' in a hospital setting. The interview schedule consisted of one question which invited the participant to reflect on their experience of health care as a service user: Can you please describe your experiences of health care? 
Dinkins (2005) points out; the researcher is the 'instrument' through which data are collected' (p. 111). In this way my abilities as a hermeneutical phenomenological researcher enabling participants to recall their experiences as service users, and reflect upon them, have a direct impact 'on the quality of data obtained' (Dinkins, 2005, p. 111). During the initial enquiry from potential participants, I described what the research was about, and what I would like them to talk about. In this way lesbian women participants could think, and reflect on their experiences, in their own time and space, prior to the interview.

During the course of the interview, further questions arose from the information the interviewee imparted. In some cases I asked very little as the lesbian woman began to tell her story, and spoke freely, with no need for my intervention. When I did intervene, it was to seek clarity on statement(s) or issue(s) which arose, but were left undeveloped, or hung in the air inviting clarification. Interviews were unstructured in format, allowing the participant to tell her story as she wished. To disguise their identity, the pseudonyms used are of Old Irish origin. They are known as Aibheann, Bébinn, Gormlaith and Ríoghnach.

Aibheann is a 30 year old single woman who had a history of admissions for procedures arising from gynecological issues, which she indicated were part of her medical history, and the history of both her mother's and father's family. Aibheann was out to her family, friends and co-workers. It is this sense of self that she brought with her when she was 
admitted to hospital. The interview took place in April 2006 when she discussed an experience of health care that had occurred in November 2005.

Bébinn is a European ${ }^{\mathrm{i}}$ lesbian woman who resides in urban Ireland and was interviewed in May 2006. She spoke of her partner Finnsech, also 23 years old, in relation to her health care experience which took place in December 2004. At the time of interview they had been together for three years. In her professional life Finnsech is a nurse. Bébinn came out to her family when she was 16 years old and has lived her life openly ever since.

Ríoghnach is a 50 year old woman living with her partner Laoise who is 43 years old. They have been together for twenty years living in an urban setting. Ríoghnach has had numerous hospital admissions, and, at the time of the interview, was diagnosed as terminally ill. Ríoghnach and Laoise have been out to their family, friends and coworkers for the last eighteen years. The interview took place in April 2006.

Gormlaith is also a 50 year old woman living in a small rural town and was recovering from breast cancer. The interview took place in May 2006 when Gormlaith chose to discuss her experience of breast cancer which was diagnosed in March 2004. She has been in a relationship with her partner Cellach who is 47 years old for the past eighteen years. In their professional lives both women are nurses. Both women have lived their lives openly to family, friends and some co-workers for the past fifteen years.

\footnotetext{
${ }^{i}$ Bébinn migrated to Ireland from another European country and found that her hospitalisation required a next of kin. Since none of her family resided in Ireland she chose her partner to be her next of kin.
} 


\section{Data analysis}

Initially my experience of interpreting the data was that of being in the dark. Questions flooded my consciousness when it came to writing the interpretation of the data. How was I to go about it? What did it mean to write? Would I get it right? Would I represent the voices of the lesbian women who participated in this research adequately? Van Manen (2002 p. 2) states that 'the writing remains painful, difficult, disorienting'. Yet it is through this process of disorientation and difficulty that something emerges.

Through writing, re-writing and re-writing a text emerged. However the question remains, how did the text happen? At the point of choosing the research topic, the hermeneutic circle begins. I must remain within the hermeneutic circle throughout the process, though I can go back and forth (Ironside 2005). Krell (1993) suggests

'In poetry we are less disposed to manipulate things or reduce them to our own technical-scientific, quantitative frames of references; we are encouraged to let things be what they are and show their many-sidedness' (p. 344).

In this sense I let poetry speak to me as it is voiced or written. I sit with it and allow it to seep into me. This is the approach I took with the data. The data was collected on an IPod, and downloaded onto compact discs. I spent time with the data through the spoken word, listening to the lesbian women describe their experiences. I listened to the voices of lesbian women when I was in the car, out walking, or at home. Like poetry the voices of lesbian women soaked into me, enabling an understanding to emerge of what was being said. At the same time I was delving into the work of both Heidegger and Sartre. When I came across issues in the voices which triggered a thought whether of a 
Heideggeran, or a Sartrean way of thinking, I would consult them ${ }^{\text {ii }}$ to develop my interpretation further. Both processes go hand in hand. Data was arranged through the headings that emerged from the voices of women and order was put on the data to enable a logical flow to my writing.

\section{Limitations of the research}

Hermeneutic phenomenology claims that the meanings and understanding of everyday life 'are bound by context' (Esterfan, McAllister \& Rowe 2004, p. 36). The findings of this research, conducted in Ireland, in 2006 with a small number of participants, are not generalisable. Van Manen (2002) suggests hermeneutic phenomenology writing does 'not yield absolute truths, nor objective observations' rather, 'at best gains an occasional glimpse of the meaning of human experience' (p. 7). A phenomenological research approach is always only one interpretation, which is presented here. This is my interpretation of the experiences of the four lesbian women presented here.

\section{Findings}

This section analyses the theme of 'coming out' in health care, as it emerged from the interviews with the four lesbian women, when they were hospitalised. The Irish women's health care strategy advocates for woman-friendly health care, creating a service that 'should not further marginalise women who are already marginalised'

\footnotetext{
${ }^{i i} H e i d e g g e r$, M. (1962). Being and time. Translated by John Macquarrie and Edward Robinson. Harper and Row, Publishers, Incorporated: New York.

Sartre, J.-P. (1969) translated by Barnes, H. E. Being and nothingness: An essay on phenomenological ontology. London: Routledge.
} 
(Government of Ireland 1997, p. 54). This section will explore whether this is being implemented, and is divided into six parts: the first deals with the experience of coming out in a hospital setting; the second reviews how the self can be alienated; the third explores the meaning of touch in health care; the fourth explores how a lesbian patient avoids detection in a hospital setting; the fifth investigates diversity in Irish health care and the sixth, uncovers the existence of a lesbian friendly health service

\section{Coming out in a hospital setting}

Aibheann had the expectation that the health care profession was aware of lesbian existence in Irish society. However her expectations were shattered when the prejudice of her health care professional was disclosed. This is her story:

One of the registrars, when I was there, was talking to me and whatever and she was saying, when was the last time you had sex, and when was the last time you had intercourse, and when was the last time, and I'm not one to get embarrassed or anything like that, but then she started getting down to the nitty gritty, and I was just thinking this woman does not have a clue what it's like to be gay in this country, and have someone asking you questions like this. Then it came down to something very personal, and she said, and I was kind of out of it at this time probably as well, ... I don't know what they gave me, but I think I was starting to float away and she said well have you ever had sex with a man and I went "why is it relevant", and she went "oh well I need to know". I went, "well no", and she said "oh well technically you're still a virgin" and I went "I'm sorry I'm what? Excuse me, can you just repeat what you just said" and she did. I was kind of there, whatever your perception of, I can't even remember what I said to her right now, but it wasn't very flattering, even though I kept my composure and didn't use any bad language, but I was not impressed. Not only did she bring this up on the first morning I was admitted, but everyday I was there she made reference to that, everyday I was there and this was last November [2005] and I couldn't believe it. I was there, who does this person think she is (Aibheann).

Like other people, lesbian women are vulnerable when they are in hospital, and they expect that health care professionals have an understanding of their situation. However, 
what Aibheann's story indicates is that some health care professionals are not only unaware of lesbianism, but are also openly prejudiced towards lesbian women. Aibheann's feeling of comfort, 'starting to float away' resulting from medication as she described it, was disrupted as she was brought back to the reality of the difference in her situation. Her health care provider pronounced with authority that lesbian sex is not real sex, which is between a woman and a man. Aibheann's worth and value as a sexual human being was measured against the heterosexual norm. She was devalued as a sexual human being: ' $[\mathrm{I}] \mathrm{t}$ is only through being object that we can be given a value, assigned a worth, some "thing" that can be assessed' (Howard 2002, p. 59). Her worth, value, and understandings of who she is in the world was undermined.

Aibheann was not measured in accordance with her own community, but the general heterosexual community, the community of the assessor, that is the health care provider. Within this measurement she became a virgin. Her sexual activities were relegated to non-existence:

By far the most, you see that was the thing, what made me feel terrible was that morning in X [names urban hospital], it was almost like I felt ashamed to be gay, because this woman felt she could say that your sex life is completely irrelevant, because your partners have been female. I just thought what the hell is this woman on (Aibheann).

Sartre (1969) suggests that 'shame of self; ... is the recognition of the fact that I am indeed that object which the Otheriii is looking at and judging' (p. 261). It disrupts the sense of self, the taken-for-granted knowledge of knowing who I am. Aibheann did not allow herself to become the object of this judgment, rather she 'almost felt' but did not

\footnotetext{
iiiThe Other changes in terms of whoever is engaging with the self.
} 
quite get there, as she questioned the ability of her health care provider, the Other, to render her 'ashamed'.

Sartre (1969) suggests shame occurs once there is no freedom to be. Through questioning the validity of her health care provider to judge her, Aibheann reasserts her freedom to be. She is this being that the health care provider, the Other, judges, as she is a lesbian woman. Aibheann however has embraced herself as Sartre (1969) puts it: 'I am this self which another knows. And this self which I am - this I am in a world which the Other has made alien to me, for the Other's look embraces my being' (p. 261). The world as Aibheann understands it has disappeared from her and becomes a world that she does not recognise as it has been subverted by the Other, the health care provider. Not only has the world become alien to her, she is simultaneously alienated from the world. However, she successfully prevents the alienation of the self through questioning her health care provider.

\section{Alienation of the self}

While Aibheann managed to prevent the alienation of the self, Bébinn, on the other hand, found herself completely alienated when she came out to her provider. Bébinn was admitted to an urban hospital with suspected meningitis:

In a particular incident I was out in the hospital and I didn't have any relatives here or any that could come over and I was on my own, I was absolutely terrified and very, very ill and I had possibly, stupidly....ye know but I didn't really give a shite, told them that Finnsech was my partner and put her on my form as next of kin. I was told that she couldn't come in with me, she couldn't come either while I was being examined or while the doctor was speaking to me. She was sent out of rooms, and when I asked for her to be brought back in they wouldn't allow her. So it was a very frightening experience to be stuck on 
my own, not really knowing what was going on, I was seriously ill... and that and ye know, just having nurses not really wanting to touch me or to treat me. One incident, I went without, the sort I had, I had bacterial meningitis and I would have needed antibiotics at regular intervals and I went without them for a full day, because the particular nurses who were on refused to even look at me, let alone touch me or treat me (Bébinn).

Bébinn did not have members of her family in Ireland; she was frightened as she did not understand what was happening to her. To be ill for her was a worrisome experience (Williams 2001) and she was afforded no opportunity to share this with her nursing care team $^{\text {iv }}$.

Research has shown (Williams 2001) that sharing one's concerns with a nurse is specifically part of the nurse-patient relationship. Bébinn did not choose to come out, rather, from need she did so and felt that she did it 'stupidly', experiencing all the consequences that followed. She was not allowed to have her partner Finnsech with her and the reality of having come out led her to not being cared for by the nursing staff. She went without medication, and, equally, she was avoided by not being looked at or touched. Sartre (1969) speaks of the look to be avoided; for Bébinn the nurses avoided her look and avoided looking at her. It is through this that Bébinn is objectified by the absent look of the Other in this case the nurses on duty. She has become the kind of person to be avoided, through not being looked at, thus becoming stigmatised (Goffman 1963).

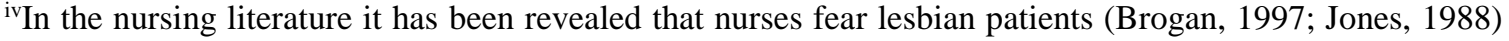
and considered patients sexuality as none of their business (Harrison, 2001). Other studies pointed to nurses being ill prepared to care for lesbian patients (White, 2002; Morrissey and Rivers, 1998). This is also cited in the HSE (2009) report on LGBT Health.
} 
In this instance it was more than avoidance, it was extreme prejudice in action whereby nurses withdraw their care from Bébinn. MacGréil (1996) suggests that avoidance:

'is a common minority response to dominant postures not perceived to be friendly or desirable by the members of the society. Sometimes it may be the only option open to a relatively weak minority in the face of dominant group hostility' (p. 51).

While MacGréil views avoidance from the perspective of minority groups or individual members' action(s), in Bébinn's situation it was the action of the dominant group, that is, heterosexual nurses, in relation to her care, which led to avoidance. The gaze is that of the professional nurse rather than the look of a friend or stranger. The nurse looks at a patient to access and guide her/him in clinical practice. Equally, a nurse utilises the look to reassure and comfort the patient through being there (Fredriksson 1999). Within this situation Bébinn became the Other, for the nurse, her similarities to the nurses, that is, as a woman, are negated and her difference is exposed through isolation. She became the difference in womanhood and exposed the fact that not all women are the same; that diversity exists. Bébinn was to be avoided and she experienced the hostility of the dominant group.

Lesbianism was something the nursing team could not cope with; they also lacked empathy with their patient. Empathy is considered 'essential for unimpaired moral judgements and behaviour' (Myhrvold 2003, p. 35), and is deemed an important element of caring. However, the actions of nurses, or rather lack of them, removed the integrity of Bébinn's being. Naef (2006) utilises the term 'bearing witness', indicating that this broadens the nurse-patient relationship as it is: 
'a special way of being with persons because it involves being attentive to persons lived experiences and truth, honouring uniqueness in respecting different ways of living a situation, supporting persons' choices, espousing the belief that persons know themselves best, and recognizing human interconnectedness' (p. 147).

For the nursing staff caring for Bébinn, there was no special way of caring, of being with her. Her interconnectedness with humanity was severed by the lack of bearing witness. Consequently, the truth of her everyday life was not explored or recognised while the truth of the dominant group was reinforced by exclusion. The underlying message was that the nurses Bébinn met only cared for those like them, that was, heterosexual women.

\section{Touching the Other}

Within nursing literature there is a distinction made between physical touch and therapeutic touch (Gleeson \& Timmins 2005). The latter is considered part of the healing process. However, Gleeson \& Timmins (2005) and Chang (2001) suggest that little consideration is given to physical touch in nursing research. It is the elements of physical touch, which is considered an integral part of the nurse-patient relationship (Routasalo 1999) leading to communication (Shakespeare 2003), giving comfort to patients (Gleeson \& Timmins 2005) and portraying acceptance of the patient (Fredriksson 1999). Through touch the nurse makes contact with the patient, provides reassurance and a sense of being cared for:

'[T] temperature; and touching is also about emotions, care, relationships, gender, intimacy, age and well-being' (van Dongen \& Elema 2001, p. 150).

However Bébinn was denied this by the actions of the nurses who cared for her, as she was denied both touch and verbal communication. By not touching her, the nursing staff 
suggested to Bébinn that she was somehow infectious or rather, that nursing staff could catch what she had: her lesbianism. While Routasalo (1999) perceives touch as an enabler in turning the patient towards communication, for Bébinn the lack of communication was a turning towards her difference. She understood this and knew that she was denied full care because of her sexuality.

Routasalo (1999) points out that not 'all nurses touch patients more than is necessary to perform a task' (p. 846). This indicates that to carry out certain tasks nurses need to or have to touch patients; it is not something they can avoid. Fredriksson (1999) on the other hand suggests that non-touch is utilised by the nurse, to protect her/himself from the suffering of her/his patient(s); however in this instance non-touch may have been utilised to protect the nurse from the negativity she felt around lesbianism. Even if we take touch in nursing as task-orientated or part of professional care (van Dongen \& Elema 2001), Bébinn's experience was that the basic tasks of her care were not executed and more importantly, the nurses had abandoned their professionalism. Her body became the untouchable object ${ }^{\mathrm{v}}$. Nevertheless, it is the taken-for-granted aspects of nursing care that were denied here. Bulfin (2005) makes a pertinent point in relation to this: 'caring between the nurse and one nursed enhances personhood' (p. 314). She indicates that the nurse through her/his caring practice enhances the individual being

\footnotetext{
${ }^{\mathrm{v}}$ During the early years of the HIV/AIDS pandemic gay men were the untouchables. This emanated from the lack of knowledge and prejudice that existed around HIV/AIDS and gay men (Albarran and Salmon, 2000). While much has been done to alleviate this situation for gay men, this would appear to have not filtered down to lesbian women.
} 
nursed and allows them to grow as a person. In this case Bébinn's personhood and growth were stunted.

Bébinn indicated that she did not need nurses for the physical aspects of her care as her partner provided it:

Oh! I didn't need any of that, I was ok. Finnsech really looked after me. I didn't need any nursing care for that (Bébinn).

However, she was aware that if Finnsech was not a nurse then as she said; 'I would have

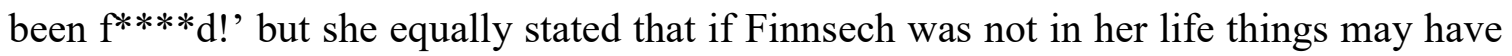
been different:

Yeah! But then if I hadn't have had Finnsech, they wouldn't have known I was lesbian and I would have got tip-top care I'm sure! (laugh) (Bébinn).

Bébinn gave meaning to the care or lack of care she experienced emanated from her sexuality. If she had not stated she was a lesbian then nobody would have known and she would have received the appropriate care. Her difference would not have been exposed. She found meaning in the conundrum of her difference; if she had passed as straight she assumed sarcastically she would have received 'tip-top care I'm sure!' Consequently, Bébinn became one of the categories of patients that are untouchable, a situation which is not new to the lesbian and gay community.

\section{Avoiding the Other}

The environment of the hospital differs to that of society, and this is where the reality of being a lesbian woman must be navigated, particularly if she wants to keep her sexual 
orientation hidden. Ríoghnach has had numerous hospital admissions; she described her experience of being a patient:

Now, when I'm in hospital, I'm in a room for women, I am always aware that I'm gay, and I will not stare people. I get very, very shy. I get to the bathroom as soon as I can, and I sort of have tunnel vision, and I'd be afraid that somebody would complain about my behaviour or something like that, although just talking to somebody, but because your chart says your orientation or whatever, it might go against you, so I do have a problem, now and especially if there's a nice woman there, you know yourself (Rioghnach).

Ríoghnach recalled she was constantly sensitive of who she is, a 'gay' woman, and how a survival strategy was put in place to avoid detection. Her tactic includes: changing who she is from outgoing to 'shy', getting early to the bathroom, and having 'tunnel vision' enabling her to prevent discovery.

Heidegger (1969) indicates that '[T]o every being as such there belongs identity, the unity of the self' (p. 26). It is the unity of the self that can be called into question, if patients discover that amongst them there is a lesbian woman. In other words, the 'unity of the self' is every facet that makes up the unit. The presence of the Other forced Ríoghnach to curtail her behaviour, so that she did not 'stare people'. Through this she experienced fear of the consequences of being exposed as it 'might go against you'. While Ríoghnach protected her identity when she was a patient, she did not indicate whether her strategies were breached. In this way she had no way of knowing how Others would react to her being a lesbian woman.

In relating her experience, Ríoghnach revealed her awareness of setting up barriers to protect the self, thus denying herself a full encounter with Other patients. 
I like to be beside the window, where I have a distraction. It's not that you're sitting there ogling women all day, but like, when you have women in their night attire all the time, and conversations going on, it's funny slagging men off or whatever, whatever, and you want to enter into it, but you don't know what they're saying, it can be embarrassing and it can be very isolating (Ríoghnach).

The window can be seen as a mechanism of the "look to be avoided" (Sartre 1969, p. 258). The window acted as an escape route by which the Other, the patients, did not enter into her realm, just as the conversations in the ward acted as barriers to her participation and domain of reality.

However, Sartre (1969) suggests that "Being-seen-by-the-Other" is the truth of "seeingthe-Other"' (p. 257). For the lesbian woman, the truth of being-seen-by-the-Other is that the Other knows who she is. Equally, to know the self is to know how the Other sees her. Ríoghnach comprehended this; her knowledge of existing as a lesbian woman in Irish society informed her, and that was what stopped her from being-seen-by-the-Other. It was through this knowing that Ríoghnach filtered information about the self to Others.

Ríoghnach was always aware that other patients shared the space of a ward and avoided looking at them. She cannot influence the interpretations that Others, the patients and nurses, put on the look. For example, the look of an admirer is different from the look of a friend or stranger, and can be said to be culturally understood regardless of sexual orientation. Ríoghnach indicated that she feared that 'my[her] look' gave off a meaning that did not exist. This calls into question whether a fellow patient is a patient or something else, for example an object of desire. Ríoghnach recognised this, but was also 
aware that she possibly missed out on authentic conversation(s), that is, conversation(s)

where she can be herself without hiding her sexual orientation.

Ríoghnach's fear may not be the reality, and she did not risk it as she did 'what is right for me':

It's just like I put on the 2 cloaks wherever I go, and if I was a straight woman and there was a gay woman looking at me, how would that make me feel? It'd make me feel uncomfortable. It's like as if I was a straight woman, and a man would be ogling me, that would make me feel uncomfortable too, you see. I sort of saw both sides, and I try and do the right thing for me. That would be my only problem, and it's a problem that I create myself. It's not a problem, but it's a problem that I have actually created in isolating myself, in choosing to isolate myself as a safeguard, although they may just embrace me if they knew I was gay or whatever, or it might set up a whole topic of conversation, and it might be a wonderful thing you'd be encouraged to come out, or whatever, but that's not why I'm there. I'm there to get an operation and to try and get well, and get out (Ríoghnach).

Ríoghnach uses the metaphor of the '2 cloaks', namely, cloaks that can hide or reveal what is underneath. The cloak was in her control as she decided whether to open it and show her true self, or to use it as a protective device, to pass within whatever situation she found herself in. This use of the cloak as a patient, was a well tested and trusted mechanism that she employed in society to protect her identity. She brought this into the hospital environment whereby she choose to 'isolate her [my]self' which acted as a 'safeguard'.

While this was a problem that Ríoghnach created for herself, it was a system she puts in place to protect the self from the Other. She justified this, by stating that her role as a patient was 'to get an operation, and to try and get well, and get out'. Through this, she indicated that she felt under no obligation to communicate on an authentic level with 
Others, that is, patients. However, Ríoghnach was also aware that there may be positive outcomes: if the Other knew her sexual orientation, this could have led to healthy debate(s) or a coming out experience(s). Nevertheless, she was not prepared to risk this, as the fear of negativity overrode the possibility of being positively received. She would not allow anything to take her focus off her goal to improve her health. Through living her life as a lesbian woman, Ríoghnach was conscious of judgements that the Other makes about lesbianism, and she shielded herself from those statements and attitudes in the hospital setting, even though she recognised that this that is judgements of Others might not be the case.

\section{Diversity in health care}

In reviewing the European Charter of Patient's Rights and its application to Ireland, O’Mathúna et al (2005) wrote that '[S]teps must be taken to ensure that access to health care services is available without discrimination and on the basis of people's health care needs' (p. 133). In 2005, it was O'Mathúna et al stated that health services should be provided in a non-discriminatory manner as well as taking into consideration the needs of the patients, which was already one of the aspirations of the women's health care policy in 1997 (Government of Ireland 1997). It is clear from the preceding stories that these principles have not been achieved for Aibheann, Bébinn, and Ríoghnach. During the consultation process that preceded the development of a women's health care policy, women had identified: '[M]ajor deficits ... [which] ... were the difficulty women experienced in accessing information on health and health services, ..., and the fact that the health services are not woman-friendly' (Government of Ireland 1997, p. 5). 
Indeed, Aibheann's and Bébinn's experiences, suggest that a woman-friendly health service was not available to them, in spite of this being one of the goals of the women's health policy. More importantly though, as Zack (2005) states, '[T]here is no question that women are different' (p. 2); this point seems to have escaped some medical providers and resulted in uneven provision of health care. Aibheann and Bébinn experienced both covert and overt prejudice during their hospital stays; Gormlaith on the other hand experienced a completely different health service.

\section{A glimpse of a lesbian friendly health service}

While this was Gormlaith's story, what becomes apparent is that it was also the story of a couple coping with breast cancer, as when Gormlaith was admitted to hospital for treatment:

Cellach and I sat in the waiting area, and didn't know what was what. Then on Monday we went to see X (names consultant), and Cellach sat there with me, and you know those private places they're all posh, not that its not the public sector, he said you know. Gormlaith, I'm X, pleased to meet you, he said: would you like to come in and would you like to bring anybody with you. I said I'd like to bring Cellach my partner with me. We went in and not even a blink, and right from that moment, and right through a series of events in between it, we have seen because it's our cancer or was our cancer, but right from then till the $26^{\text {th }}$ March, it's been our cancer, and its been our consultant, right down to decision-making, what do you want to do? I looked at Cellach and said: what shall we do? and she said it's up to you, and right from that first day, his engagement and all of his team's engagement now we met, as you know, you get medics changed every 6 months, and for every appointment, Cellach was there right by my side, in every sense of the word, there was never a blink of an eye, there was never nothing. From day one we had a private room, all the nurses were most respectful, very would you like be on your own? No I want Cellach to stay with me, even right up till 11o'clock (Gormlaith). 
From Gormlaith's story, we see how her sexual orientation was not an issue; she was able to be herself and have her partner Cellach with her during her first consultation, and throughout her treatment. She was afforded the opportunity to be, herself from the beginning of her treatment. She spoke of her experience of breast cancer as affecting both Cellach and herself: it was 'our cancer', not Gormlaith's, but Cellach's as well. It was something both of them had to learn to live with and work through together. The decision-making was a joint project to be worked through where both women could live with the outcome.

Neither Gormlaith nor Cellach became the Other ${ }^{\mathrm{vi}}$ in the eyes of their health care team. Unlike Bébinn, who had her partner Finnsech outside the room during consultations with her medical provider, Gormlaith and Cellach were seen together and, consequently, the reality of the truth of their situation was acknowledged. Their need to be and care for each other was never questioned, but acknowledged and facilitated by the care team. This reflects a health care service based on trust and mutual respect (Ward \& Savulescu 2006), in which the patient-as-person and the doctor-as-person (Mead \& Bower 2000) were encapsulated.

Ultimately, what Gormlaith and Cellach experienced, was a patient-centred health service whereby both the medical staff and nursing staff were either educated practitioners (Albarran \& Salmon 2000), or health care professionals, who could provide

\footnotetext{
vi The Other changes in terms of whoever is engaging with the self.
} 
care regardless of their understanding of different modes of living (Naef 2006). As Gormlaith describes:

They were absolutely fabulous you know they would say, Cellach would you like a cup of tea? it was like as if we were joined at the hip. Right through, from the first surgery, and then unfortunately, they didn't get rid of all the cancer the first time round, and they also discovered it in the lymph nodes, which that meant chemo every two weeks up in Y, so then there was the second surgery in April, same thing in there, herself, curtains around, sitting on my bed, the whole shebang, not even the blink of an eyelid, X (names consultant) his whole team, the breast care staff (Gormlaith).

No member of her care team had any problem with her relationship, even to the point that she reflects that they thought they were 'joined at the hip'.

From a Heideggerian (1962) perspective, Gormlaith and Cellach experienced the authenticity of the self. Through this, Gormlaith's illness opened to them the possibility of becoming authentic (Heidegger 1962). When Heidegger (1962) speaks of 'being authentic' he suggests that it is a choice. Gormlaith chose her authenticity by seeing herself as a lesbian woman, with breast cancer. As a couple, both Gormlaith and Cellach also declared their authenticity by viewing the illness not only as belonging to Gormlaith, but as theirs. In this way they chose their possibility of becoming in whatever way the illness might take them. It became a part of who they were as a couple. Equally, the experience of these two lesbian women pointed to a health care service that was based upon the provision of care centred on the illness, rather than on the type of person who presented themselves. 


\section{Summary of the findings}

Aibheann and Bébinn experienced 'coming out' in health care encounters through discrimination and prejudice manifested in both overt and covert ways. Howard (2002) suggests that it is through objectification that I get a sense of worth and value of myself as human beings. Equally, inappropriate questioning by the health care provider can lead to discrimination. However, health care providers can reinforce the heterosexual norm in the face of diversity, which resulted in both women being confronted by their difference when they come out. A goal of both nursing and medical training was the production of neutral individuals who can care for patients, regardless of their attributes (Beagan 2000); however, it would also appear to be effective in reinforcing the norms and values of heterosexuality, which does not address difference properly.

Aibheann's expectation was that the health care sector would be a 'bit more progressive', in recognising diversity amongst women. Bébinn on the other hand had no expectations but came out as a way to assert her needs, that is, have an advocate by her side who could either speak on her behalf or facilitate questions. The care which both of these women received revealed discriminatory actions on the part of their providers. Aibheann's story reveals that while some lesbian women live their lives openly and securely in the knowledge of who they are, they cannot expect their taken-for-granted understandings of their life in new situations. While Aibheann had an underlying expectation that health care professionals would appreciate the reality of diversity within sexual orientation, she discovered that this was not so. Bébinn, on the other hand, trusted that her health care providers would treat her competently as she was the uninformed recipient of care. 
However, she learnt that this trust was misguided and vowed never to trust again, but rather, to question. Ríoghnach on the other hand experienced neither prejudice nor discrimination, as she implemented well tested techniques to hide who she was, from those she encountered on the ward. In contrast to the experiences of these three lesbian women Gormlaith and Cellach encountered a health care service that achieved the goal of the women's health policy (Government of Ireland 1997). namely a lesbian-friendly health care service.

\section{Policy Implications}

The Health Service Executive (HSE) indicate that they are responsible for improve the quality of care' delivered to 'all users of HSE services' as well as enhance the 'access to all services' which in this economic climate must be 'cost effective' (http://www.hse.ie/eng/about/Who/clinical/). It is therefore the responsibility of the HSE to promote and provide adequate health care provision for lesbian women. It is the policy of the Irish government that all health services are to develop an action plan to 'ensure that health professionals are informed about lesbian health issues', and that all health care staff were to 'respect the sexual orientation of lesbian women' (Government of Ireland 1997 p. 64). This policy lays down the type of action that needs to be

undertaken to create a woman-friendly health care: reviewing staff attitudes, and developing training programmes for sensitivity. This would suggest that information, per se, will not enable health care professionals to change attitudes but that training programmes also need to be implemented. 
Aibheann, Bébinn and Ríoghnach's stories would suggest that the HSE needs to review its staff training; Gormlaith and Cellach's experience suggests that the particular cancer health care had an ability to recognise lesbian relationships. In this way the two women experienced a health care service that incorporated the patient-as-person, thus recognising the patient as being-in-the-world, bringing with her all facets that make up personhood into health care. In 2010 the HSE published a patient's charter (http://www.hse.ie/). It clearly states that LGBT people should receive a service based upon respect and dignity of the person (http://www.hse.ie/).

While the Irish women' health policy (1997) had the aspiration of creating a womanfriendly health service the experiences of Aibheann, Bébinn and Ríoghnach would suggest that this has not been developed. This research reveals that while the first step in creating an inclusive health policy has been taken, a second step needs to be undertaken namely, its implementation. The stories of these women reveal the consequences for some women when health care professionals are not enabled to deal with their prejudice towards certain groups. To build a culture of inclusivity in health care a policy document needs to be more than a written text, rather it needs to become an ongoing living project, which can be developed creatively between the service user and provider of health care.

\section{Conclusion}

This article provides an analysis of the experiences of four lesbian women, of 'coming out' in Irish health care, from a hermeneutical phenomenological perspective. Van Manen (1990) informs us that this approach to research is 'always to question the way we 
experience the world, to want to know the world in which we live as human beings' (p.

5). The research illustrates how lesbian women understand and give meaning to the situations in which they find themselves. Their stories exemplify attempts to reconcile the self with a culture of health care based upon heterosexuality. This reflects initial studies (Regan 1981) and later studies (Gibbons et al. 2007) which report that diversity in women's sexuality is not recognised in health care settings.

\section{Acknowledgements:}

This article came out of research I did on the experiences of lesbian women of Irish health care. It was part-funded by the Irish Research Council for Humanities and Social Science Postgraduate Scholarship 2006-2007. I want to thank my colleagues Professor Anthony Staines and Dr. Vera Sheridan for comments, suggestions and guidance on various versions of this paper and the two anonymous reviewers provided by SRSP.

\section{References:}

Beagan, B. L. (2000). Neutralizing differences: Producing neutral doctors for (almost) neutral patients. Social Science \& Medicine, 51, 1253-1265.

Bergum, V. (1989). Being a phenomenological researcher. In J.M Morse (Ed.), Qualitative Nursing Research: A Contemporary Dialogue (pp. 54-71). London: Sage Publications.

Bonvicini, K. A \& Perlin, M.J. (2003) The Same but Different: Clinician-Patient Communication with Gay and Lesbian Patients. Patient Education and Counselling, 51, 115-122.

Bradford, J., Ryan, C., \& Rothblum, E. D. (1997). National lesbian health care survey: Implications for mental health care. Journal of Lesbian Studies, 1(2), 217-249.

Brogan, M. (1997). Healthcare for lesbians: Attitudes and experiences. Nursing Standard, 11(45), 39-42.

Bulfin, S. (2005). Nursing as caring theory: Living caring practice. Nursing Science Quarterly, 18 (4), 313-319.

Chang, S. O. (2001). The conceptual structure of physical touch in caring. Journal of Advance Nursing, 33(6), 820-827.

Chirrey, D. A. (2003). 'I hereby come out': What sort of speech act is coming out? Journal of Sociolinguistics, 7(1), 24-37.

Claassen, C. (2005). Whistling women: A research of the lives of older lesbians. New York: The Haworth Press.

Clunis, D. M., Fredriksen-Goldsen, K.I.; Freeman, P. A. \& Nystrom, N. (2005) Lives of Lesbian Elders: Looking Back, Looking Forward. New York: The Haworth Press.

Creswell, J. W. (1998). Qualitative inquiry and research design: Choosing among five traditions. London: Sage Publications.

Draucker, C. B. (1999). The critique of heideggerian hermeneutical nursing research. Journal of Advanced Nursing, 30(2), 360-373. 
Dufrenne, M. (1965). Existentialism and existentialism. Philosophy and Phenomenology Research, 26(1), 51-62.

Enszer, J. R. (1996) Health care needs of lesbians: issues and access: A report on the lesbian and bisexual women's health survey. USA: Affirmations Lesbian/gay Community Center.

Estefan, A., McAllister, M., \& Rowe, J. (2004). Difference, dialogue, dialectics; A research of caring and self-harm. In K. H. Kavanagh \& V. Knowlden (Eds.) Many voices: Towards caring culture in healthcare and healing; Interpretive studies in healthcare and in human sciences (pp. 21-61). Madison: The University of Wisconsin Press.

Fields, C. B., \& Scout (2001). Addressing the needs of lesbian patients. Journal of Sex Education and Therapy, 26(3), 182-188.

Fredriksson, L. (1999). Modes of relating in a caring conversation: A research synthesis on presence, touch and listening. Journal of Advance Nursing, 30(5), 1167-1176.

Gibbons, M., Manandhar, M., Gleeson, C., \& Mullan, J. (2007). Recognising LGB sexual identities in health services: The experiences of lesbian, gay and bisexual people with health services in North West Ireland. The Equality Authority and the Health Service Executive: Brunswick Press.

Giorgi, A. (2005) The phenomenological movement and research in the human sciences. Nursing Science Quarterly, 18(1), 75-82.

Gleeson, M., \& Timmins, F. (2005). A review of the use of clinical effectiveness of touch as a nursing intervention. Clinical Effectiveness in Nursing, 9, 69-77.

Goffman, E. (1963) Stigma. London: Penguin Books.

Government of Ireland (1997). A Plan for Women's Health: 1997-99. Dublin: Stationary Office.

Harrison, J. (2001). 'It's none of my business': Gay and lesbian invisibility in aged care. Australian Occupational Therapy Journal, 48, 142-145.

Heidegger, M. (1962). Being and time. Translated by John Macquarrie and Edward Robinson. Harper and Row, Publishers, Incorporated: New York.

Hinchliff, S., Gott, M., \& Galena, Elizabeth (2005) 'I daresay I might find it embarrassing': General practitioners' perspectives on discussing sexual health issues with lesbian and gay patients. Health and Social Care in the Community, 13(4), 345-353. Howard, P. A. (2002). "The look" in teacher's performance evaluation. In M. van Manen (Ed.), Writing in the dark: Phenomenological studies in interpretive inquiry (pp. 50-60). Canada: The Althouse Press.

Hug, C. (1999). The politics of sexual morality in Ireland. London: Macmillan Press Ltd.

Johnson, S. R., \& Guenther, S.M. (1987). The role of "coming out" by the lesbians in the physician-patient relationship. Women and Therapy, 231-238.

Jones, R. (1988). With respect to lesbians. Nursing Times, 84(20), 48-49.

Kavanagh, K. H. (2006). Beyond the individual: Healthcare ethics in diverse societies. In C. Sorrell Dinkins \& J. M. Sorrell (Eds) Listening to the whispers: Re-thinking ethics in healthcare (pp. 248-304). Madison: The University of Wisconsin Press.

Kenny, M. (1997). Goodbye to Catholic Ireland: A social, personal and cultural history from the fall of Parnell to the realm of Mary Robinson. London, Auckland, Melbourne, Singapore and Toronto: Sinclair-Stevenson.

Krell, D. F. (ed.) (1993) Martin Heidegger: Basic writings. San Francisco: Harper. 
Layte, R., McGee, H., Quail, A., Rundle, K., Cousins, G., Donnelly, C., Mulcahy, F. \& Conroy, R. (2006). The Irish research of sexual health and relationships. Dublin: Department of Health and Children and Crisis Pregnancy Agency.

Lemon, G., \& Patton, W. (1997). Lavender blue: Issues in lesbian identity development with a focus on an Australian lesbian community. Women's Studies International forum, 20(1) 113-127.

Lehmann, J. B., Lehmann, C. U. \& Kelly, P. J. (1998). Development and Health Care Needs of Lesbians. Journal of Women's Health, 7(3), 379-387.

Letherby, G. (2003) Feminist research in theory and practice. Buckingham: Open University Press.

MacGreil, M. (1996). Prejudice in Ireland revisited. Maynooth: The Survey and Research Unit, Department of Social Studies.

Marrazzo, J. M., \& Stine, K. (2004). Reproductive health history of lesbians: Implications for care. American Journal of Obstetrics and Gynecology, 190, 1298-1304.

Marrazzo, J. M., Coffey, P., \& Bingham, A. (2005). Sexual practices, risk perception and knowledge of sexually transmitted disease risk among lesbian and bisexual women. Perspectives on Sexual and Reproductive Health, 37(1), 6-12.

McDermott, E. (2004). Telling lesbian stories: Interviewing and the class dynamics of 'talk'. Women's Studies International Forum, 27, 177-187.

McDonald, C., McIntyre, M., \& Anderson, B. (2003). The view from somewhere: Locating lesbian experience in women's health. Health Care for Women International, 24, 697-711.

Mead, N., \& Bower, P. (2000) Patient-centredness: A conceptual framework and review of the empirical literature. Social Science \& Medicine, 51, 1087-1110.

Moran, D. (2000). Introduction to phenomenology. London: Routledge, Taylor and Francis Group.

Morrissey, M., \& Rivers, I. (1998). Applying the Mims-Swenson sexual health model to nurse education: Offering an alternative focus on sexuality and health care. Nurse Education Today, 18(6), 488-495.

Myhrvold, T. (2003). The exclusion of the Other: Challenges to the ethics of closeness. Nursing Philosophy, 4, 33-43.

Naef, R. (2006). Bearing witness: A moral way of engaging in the nurse-person relationship. Nursing Philosophy, 7, 146-156.

Norman, J., Galvin, M., \& McNamara, G. (2006). Straight talk: Researching gay and lesbian issues in the school curriculum. Dublin: Centre for Education Evaluation, School of Education Studies, Dublin City University.

O'Connor, P. (1998). Emerging voices: Women in contemporary Irish society. Dublin: Institute of Public Administration.

Phellas, C. N. (2000). Cultural and sexual identities in in-depth interviewing. In C. Truman, D. M. Mertens \& B. Humphries (Eds.), Research and inequalities (pp. 52-64). Dublin: University College London Press.

Reagan, P. (1981). The interaction of health professionals and their lesbian clients. Patient Counselling and Health Education, 3, 21-25.

Routasalo, P. (1999). Physical touch in nursing studies: A literature review. Journal of Advanced Nursing, 30(4), 843-850. 
Rust, P. C. (1993). "Coming Out" in the age of social constructionism: Sexual identity formation among lesbian and bisexual women. Gender and Society, 7(1), 50-77.

Sartre, J.-P. (1969) translated by Barnes, H. E. Being and nothingness: An essay on phenomenological ontology. London: Routledge.

Sauliner, C. F. (2002). Deciding who to see: Lesbians discuss their preferences in health and mental health care providers. Social Work, 47(4), 355-365.

Shakespeare, P. (2003). Nurses' bodywork: Is there a body of work? Nursing Inquiry, 10(1), 7-56.

Spinks, V. S., Andrews, J..\& Boyle, J. S. (2000). Providing Health Care for Lesbian Clients. Journal of Transcultural Nursing, 11( 2), 137-143.

Tiemann, K. A., Kennedy, S.A. \& Haga, M.P. (1998). Rural Lesbians Strategies for Coming Out to Health Care Professionals. Journal of Lesbian Studies, 2(1), 61-75

Van Dongen, E., \& Elema, R. (2001). The art of touching: The culture of 'body work' in nursing. Anthropology and Medicine, 8(2/3), 149-162.

Van Manen, M. (2002). Writing in the dark: Phenomenological studies in interpretive inquiry. Ontario: The Althouse Press.

Ward, M., \& Savulescu, J. (2006). Patients who challenge. Best Practice \& Research Clinical Anaesthesiology, 20(4), 545-563.

White, I. (2002). Nursing as a sexualised occupation. In H. Heath and I. White (Eds.), The challenge of sexuality in health care (pp. 51-65). Oxford: Blackwell Science.

White, J. C., \& Dull, V. T. (1997). Health risk factors and health-seeking behaviour in lesbians. Journal of Women's Health, 6(1), 103-112.

Williams, A. (2001). A research of practising nurses' perceptions and experiences of intimacy within the nurse-patient relationship. Journal of Advance Nursing, 35(3), 188196.

Wojciechowski, C. (1998). Issues in caring for older lesbians. Journal of Gerontological Nursing, 24(7), 28-33.

Zack, N. (2005). Inclusive feminism: A third wave theory of women's commonality. Lanham: Rowman \& Littlefield Publishers Ltd. 